\title{
Influence of an Inlet Rotating Axial Device on the Cavitation Processes in a Low Specific Speed Centrifugal Pump
}

\author{
Moloshnyi O. M. ${ }^{1 *}$, Szulc P. ${ }^{2}$, Sotnyk M. I. ${ }^{1}$
}

${ }^{1}$ Sumy State University, 2 Rymskogo-Korsakova St., 40007 Sumy, Ukraine;

${ }^{2}$ Wroclaw University of Science and Technology, 27 Wybrzeze Wyspianskiego St., 50-370 Wroclaw, Poland

\section{Article info:}

Paper received:

The final version of the paper received:

Paper accepted online:
*Corresponding Author's Address:

December 1, 2018

March 21, 2019

March 26, 2019

\author{
o.moloshnyi@outlook.com
}

\begin{abstract}
The paper is devoted to the analysis of the cavitation processes in the flow section of the low specific speed centrifugal pump. A new conception of double-entry hermetic pump leads to the application of special shaped inlet device, which is a part of an electrical motor rotating element. Four flow geometrical models of the axial inlet device were taken into consideration. The first model, treated as referential and basic, has a cylindrical shape with small diffuser and a cone in front on the impeller. Other three models consist of the motionless cone, which was part of the housing, straight pipe, and diffuser section rotating analogously to the impeller and a spherical fairing. The research was conducted using physical experiments and numerical simulations of the workflow in the ANSYS CFX software environment. The analysis of the results shows that the pump with the basic model of the inlet device has NPSH $3 \%$ above the average values. The comparison between CFD and experiment of the cavitation curves shape showed its similarity but determined by means of the physical experiment have higher values. Cavitation in the impeller starts earlier than in the axial inlet device. The zones of the cavitation in the axial inlet device are located after the cone, at the beginning of the diffuser section and near the fairing at the outlet of the diffuser section. The cavitation zone, which is located after the cone, is separated from the walls of the axial inlet device. The value of the NPSH $3 \%$ increases, when the diameter of the axial inlet device decreases, as the result of the raise of head loses in the inlet structure.
\end{abstract}

Keywords: inlet chamber, inlet nozzle, intake section, suction casing, cone, diffuser, CFD, NPSH, cavitation performance.

\section{Introduction}

Cavitation is a negative phenomenon that can occur in a pump. Its appearance in the preliminary phase leads to the increasing of the pulsation of a pressure, as well as the raise of the vibration and noise. Further development of the cavitation reduces the head and the efficiency of the pump. A consequence of the long cavitation process, the destruction of the impeller material could be observed. Therefore, scientists and engineers are devoting a lot of attention to the study and understanding of the cavitation phenomenon and ways to reduce the likelihood of its occurrence in rotating machinery.

As it is known, the greatest influence on the appearance of cavitation has the pressure at the impeller inlet and the temperature of the water. Moreover, the structure of the flow at the impeller inlet has also significant impact on the cavitation performances of the pump. It is determined by the shape and geometrical parameters of the inlet device, the inlet part of the impeller, the leading edges of the blades, the design of an inducer (if it is) and, of course, of the rotating speed.

\section{Literature Review}

The most popular method for eliminating cavitation in the impeller is the addition of the inducer [1]. However, in this case, cavitation may occur on the inducer blades. To weaken the cavitation processes Jiang et. al [2] proposed additional flow jets in front of the inducer. Tkach [3] demonstrated the benefits of using a stator sleeve with ribs around the inducer to reduce the cavitation erosion.

Si et. al [4] presented a method for improving the cavitation performances of the centrifugal pump by introducing a jet flow into the pump inlet device. However, the 
cavitation performances of the pump deteriorated with the increase of the flow rate.

Tan et. al $[5,6]$ discovered, that the cavitation performances deteriorate when the pump is regulated by prewhirl of the flow by inlet guide vanes in front of the impeller. At the same time, there was a slight increase in pressure and efficiency. Skerlavaj et. al [7] discovered a decrease in the cavitation area on the suction side of the blades when the fluid is swirled in the symmetric inlet casing. However, Nagahara et. al [8] discovered that a large swirling of the flow in the inlet device of the vertical pump led to the formation of a cavitation vortex.

According to the results of the experiment conducted by Sikora et. al [9] the process of the appearance of the cavitation bubbles in a direct inlet pipe was accompanied by a decrease in volume flow. Cucha et. al [10] presented a comparison of the results of a numerical and an experimental study of cavitation in the nozzle. The cavitation zone occurs immediately after a sudden entry into the nozzle and is stretched under the walls.

Hergt et. al [11] found that the diffuser before the impeller reduces the length of the recirculation zone and reduces the risk of the cavitation. In turn, Gulich [12] noted the efficiency of using the diaphragm to reduce the cavitation. Limbach [13] analyzed the pump with the diffuser but did not describe its effect on the cavitation phenomena and performances. Moloshnyi et. al [14] analyzed the cavitation processes in a pump with the similar shape of inlet device and found the cavitation zone in the diffuser. Using the sudden expansion at the outlet of the diffuser decreases their area.

The literature review shows that the influence of the change in the cross-sectional area of the inlet device and the rotation of its walls on cavitation processes in the pump are not sufficiently described.

To determine the influence of the diameter of the passage channel in the axial inlet device (AID) with rotating walls on the cavitation performances of the pump and the structure of the cavitation zones in the AID and impeller.

\section{Research Methodology}

\subsection{Object of a study}

The object of the study is a low specific speed close coupled centrifugal pump, which corresponds to half of double entry pump. Nominal flow rate $Q_{n o m}=16 \mathrm{~m}^{3} / \mathrm{h}$, head $H=10 \mathrm{~m}$, rotational speed $n=1450 \mathrm{rpm}$, specific speed $n_{q}=\mathrm{n} \cdot \mathrm{Q}^{0.5} / \mathrm{H}^{0.75} \approx 17.5 \mathrm{rpm}$. Impeller eye diameter $D_{0}=63 \mathrm{~mm}$, impeller outer diameter $D_{2}=192 \mathrm{~mm}$, the number of impeller blades $z=7$.

Four structures of the AID were dedicated for consideration and research. The construction of AID 0 was a cylindrical shape with a slight diffuser and a cone in front of the impeller (Fig. 1). The AIDs 1,2,3 were designed as an inlet device of the double entry pump. The fluid flows into the cavity of the pump shaft, which additionally is a part of the inlet device. The AIDs 1, 2, and 3 have a motionless cone at the inlet which is part of the housing, straight and diffuser sections, which are rotating with the rotational speed of the pump shaft, and also a spherical fairing. The diameter of the cylindrical section (d) for AIDs 1, 2, 3 was respectively $44 \mathrm{~mm}, 40 \mathrm{~mm}$, and $36 \mathrm{~mm}$. The diameter of the inlet pipe $\left(D_{i n}\right)$ was $65 \mathrm{~mm}$. The total length of all AID $(L)$ was $260 \mathrm{~mm}$ and the rotating AIDs section length $\left(l_{\text {rot }}\right)$ was $207 \mathrm{~mm}$. The length of the cone $\left(l_{c o n}\right)$ and the diffuser section of the AIDs $\left(l_{d i f}\right)$ was $33 \mathrm{~mm}$ and $51 \mathrm{~mm}$, respectively. The inner diameter of the outlet from the AIDs $\left(d_{\text {out }}\right)$ was $20 \mathrm{~mm}$. Overall dimensions of analyzed AIDs were limited by the dimensions of the pump housing. The maximum diffuser angle $(\vartheta)$ for organizing the uniform flow out of the diffuser was calculated by the formula given in [12]:

$$
\vartheta=16,5\left[d /\left(2 l_{d i f}\right)\right]^{0.5}=16.5 \cdot[44 /(2 \cdot 51)]^{0.5}=10.8^{\circ} .
$$

Diffuser angle of the AID 1 was assumed as $10.5^{\circ}$, which is permissible, but for other investigated AIDs, it exceeded this value.

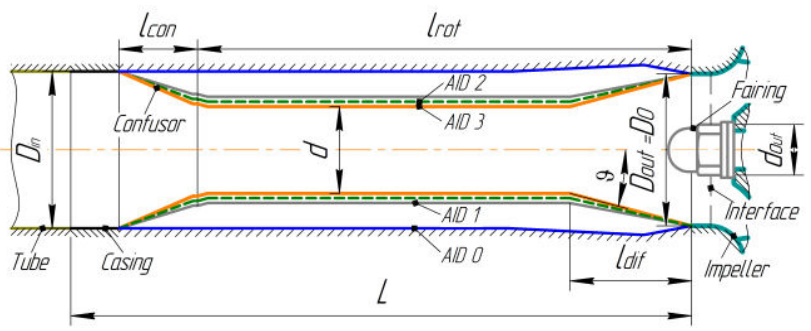

Figure 1 - Scheme of the AID models

\subsection{Physical experiment}

The physical experiment, to determine the cavitation performances of the pump with different AID structures, was conducted on a special prepared test rig (Fig. 2).

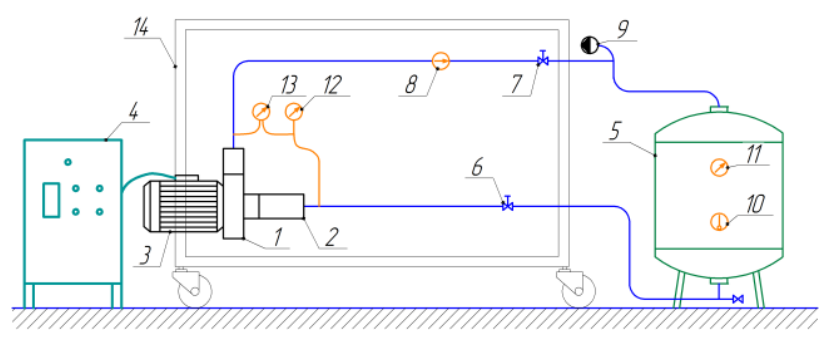

Figure 2 - Principal scheme of the experimental stand:

1 - researched pump; 2 - housing of the AID; 3 - electric motor; 4 - frequency converter with integrated powermeter;

5 - tank; 6, 7 -valves; 8 - electromagnetic flowmeter; 9 - vacuum pump; 10 - thermometer; 11 - pressure gauge; 12 - electronic pressure-and-vacuum gauge; 13 - electronic differential pressure gauge; 14 -mounting frame of the stand

Analysed pump reproduces half of the flow part of the double entry pump (Fig. 3 a). The AID, the impeller and the spiral with guide vanes of the researched pump were made from plastic using 3D-printing method (Fig. 3 b). As the material for printing PETG (Polyethylene Terephthalate Glycol) was used. The test was conducted according to ISO 9906:2012(E) Rotodynamic pumps - Hydrau- 
lic performance acceptance tests. Accuracy classes of applied measuring devices were: the electronic pressure and vacuum gauge and electronic differential pressure gauge -0.5 , powermeter -0.5 and electromagnetic flowmeter -0.5 . The pumping fluid during the test was pure water at temperature $25^{\circ} \mathrm{C}$. The physical experiment was carried out for the AIDs 0,1, and 2. During the test, the decrease of the pressure at the inlet was made by means of the vacuum pump.

\subsection{Numerical simulation}

The model of a fluid computational domain of the researched pump was constructed at the beginning (Fig. 3 a). It contains the suction and discharge pipes, the AID, the impeller and the spiral with guide vanes. Simplification of the flow domain was made by assuming that there are no sinuses in the pump, to reduce the complexity of the grid and increase the speed of the calculation. According to comparative calculations, such assumptions influenced no the results of the final calculation within $1 \%$. Numerical simulation of the flow were carried out for 4 models of the AID.

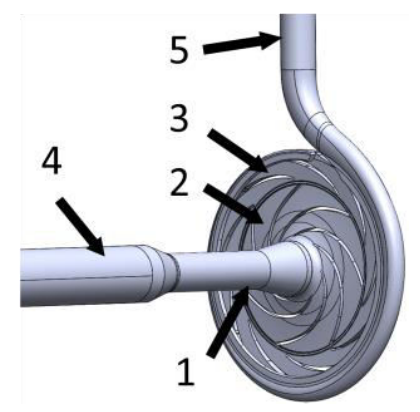

a

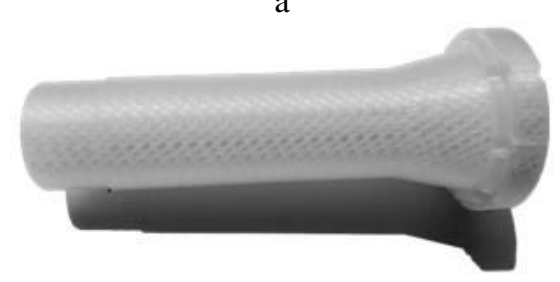

b

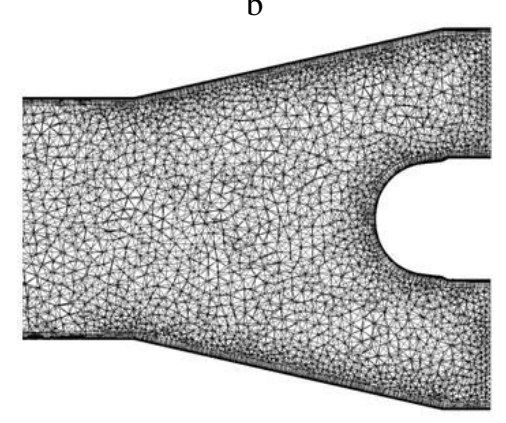

c

Figure 3 - Investigated model: a - solid model of flow parts of the pump: 1 - axial inlet device (AID); 2 - impeller; 3 - the spiral with guide vanes; 4 - suction pipe; 5 - discharge pipe; $b$ - the plastic rotating part of the AID 2; $c$ - the mesh of the diffuser section with fairing of the AID 2
The numerical simulation of fluid flow in the components of the pump was conducted using the ANSYS CFX software. The Rayleigh-Plesset equation, the standard k$\varepsilon$ turbulence model and the Reynolds equation was used. Boundary conditions were: the total pressure at the pump inlet and the mass flow rate at the pump outlet. Working fluids were water and water-vapor at temperature $25^{\circ} \mathrm{C}$. The saturated steam pressure was set as $3167 \mathrm{~Pa}$. The surface roughness of the printed elements was assumes as $25 \mu \mathrm{m}$. The numerical calculation was carried out at $(0.7$, $1.0,1.3) \cdot Q_{\text {nom }}$.

An unstructured mesh was generated using software ICEM-CFD (Fig. 3 c). Elements size was selected via mesh independence research. Layers of prismatic elements were created near solid walls in the boundary layer. The total number of nodes of the pump model was $3.3 \mathrm{mln}$. The inlet device, the impeller and the spiral contain $0.5 \mathrm{mln}, 1 \mathrm{mln}$ and $1.25 \mathrm{mln}$ nodes, respectively.

\section{Results and Discussion}

The cavitation performances of the pump for $(0.7,1.0$, 1.3) $Q_{\text {nom }}$ are determined (Fig. 4). The value of the Net Positive Suction Head (NPSH) is determined by the drop of the head value by $3 \%$ (NPSH $3 \%$ ). The basic AID has the lowest cavitation performances. According to the results of the numerical experiment NPSH $3 \%$ is $0.3 \mathrm{~m}$ at $Q_{n o m}$. The maximum NPSH3\% was achieved for the AID $3-1.2 \mathrm{~m}$ at $Q_{\text {nom }}$. The value of the NPSH $3 \%$ increases, when the diameter of the AID decreases. This is caused by an increase of the losses in the AID and the change in the structure of flow at the impeller eye.

A sharp drop of the pump head in course of the raise of the intensification of the cavitation phenomena is characteristic of the pumps with a low value of the specific speed. The smallest area of the passage channel relative to other places of the impeller is located between leading edges of neighboring blades. In the process of the developing cavitation, the vapor quickly occupies the passage between blades and leads to a breakdown of the working process of the pump. The increase of the flow rate leads to the raise of NPSH $3 \%$, which is typical for the low specific speed pumps.

The value of the NPSH $3 \%$ received during the physical experiment has higher values that the values obtained by the numerical simulation. NPSH $3 \%$ for AIDs $0,1,2$ at $Q_{\text {nom }}$ were $0.7 \mathrm{~m}, 0.95 \mathrm{~m}$, and $1.4 \mathrm{~m}$. However, the shape of curves constructed using the results of a physical experiment and a numerical simulation are similar. Some deviations between the quantity character in obtained results (numerical simulation and experimental test) are widespread in [5, 13]. Possible causes are different roughness of the walls in the numerical model and the real elements, due to features of printing technology. The surface has a micro groove in the plane perpendicular to the rotation axis, which is not taken into account in the numerical model. Additional, the numerical model was the simplification of the real pump and the volumetric losses was not simulated, which can be bigger than nor- 
mal in case of non-symmetrical clearance in the seals. That is why the results can be considered as accepted.

An important criterion for evaluating the occurrence of cavitation in the pumps with geometrically non-similar inlet device is the suction specific speed $n_{s s}$. It is defined as [12]:

$$
n_{s s}=n \frac{\sqrt{Q_{\text {nom }} / f_{q}}}{\mathrm{NPSH}_{3}^{3 / 4}},
$$
ler.

where $f_{q}$ is the number of the impeller eyes per impel-

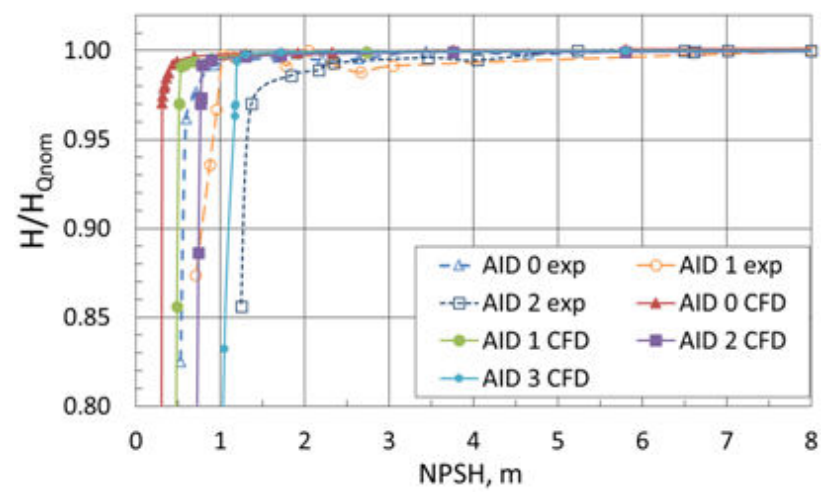

a

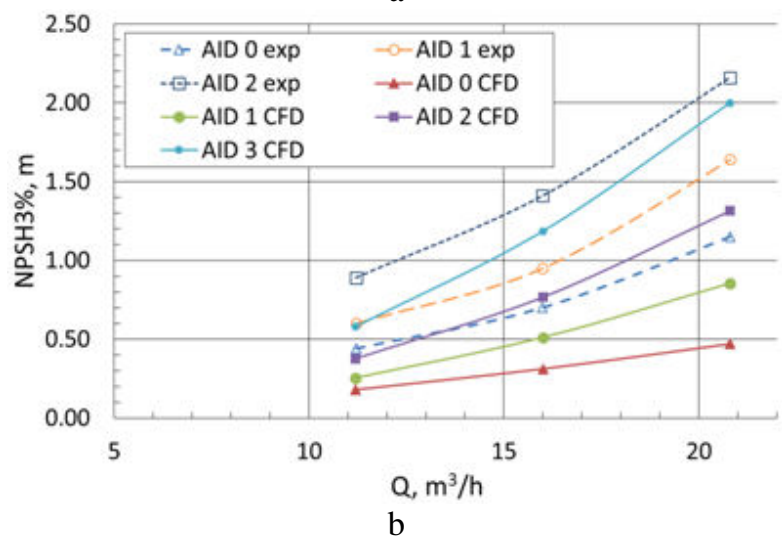

Figure 4 - Comparison of the cavitation performances curves: $\mathrm{a}$ - head-drop curves at $\mathrm{Q}_{\text {nom }} ; \mathrm{b}$ - NPSH $3 \%$ curves at $(0.7 ; 1.0 ; 1.3) \cdot Q_{\text {nom }}$

The calculated value of the suction specific speed at $Q_{n o m}$ for AIDs $0,1,2,3$ is respectively $231,160,118$, and 85 . Typical values for centrifugal pumps with a standard impeller and an axial or semi-spiral inlet device are in the range of 160-220 [12]. That is, the AID 0 has better performance than standard pumps, AID 1 has a permissible value and AIDs 2, 3 have understated. However, it should be noted that the baseline for comparison is taken for pumps with a higher specific speed than the considered pump.

The AID 2 has a good head, energy, cavitation performances and also has the most optimal dimensions in terms of design features. More could be found in [15]. For further analysis, the AID 2 was adopted.

The first occurrence of the cavitation was observed in the impeller at the suction side of the blades (near the leading edge) (Fig. 5 a). It is caused due to the flowing around the blades and the deviation of the direction of the flow. That means, the blade angle is too large and real $Q_{\text {nom }}$ at bigger value is approximately $17 \mathrm{~m}^{3} / \mathrm{h}$. This is confirmed by Limbach [13]. These zones are larger in the AID 0 than in the AID 2 for $N P S H=3.76 \mathrm{~m}$ at $Q_{n o m}$. However, their size does not affect the change in the pump head.

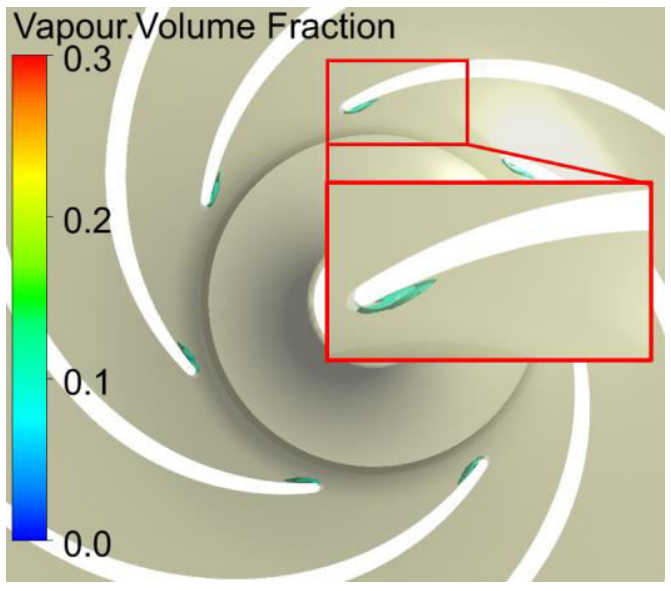

a
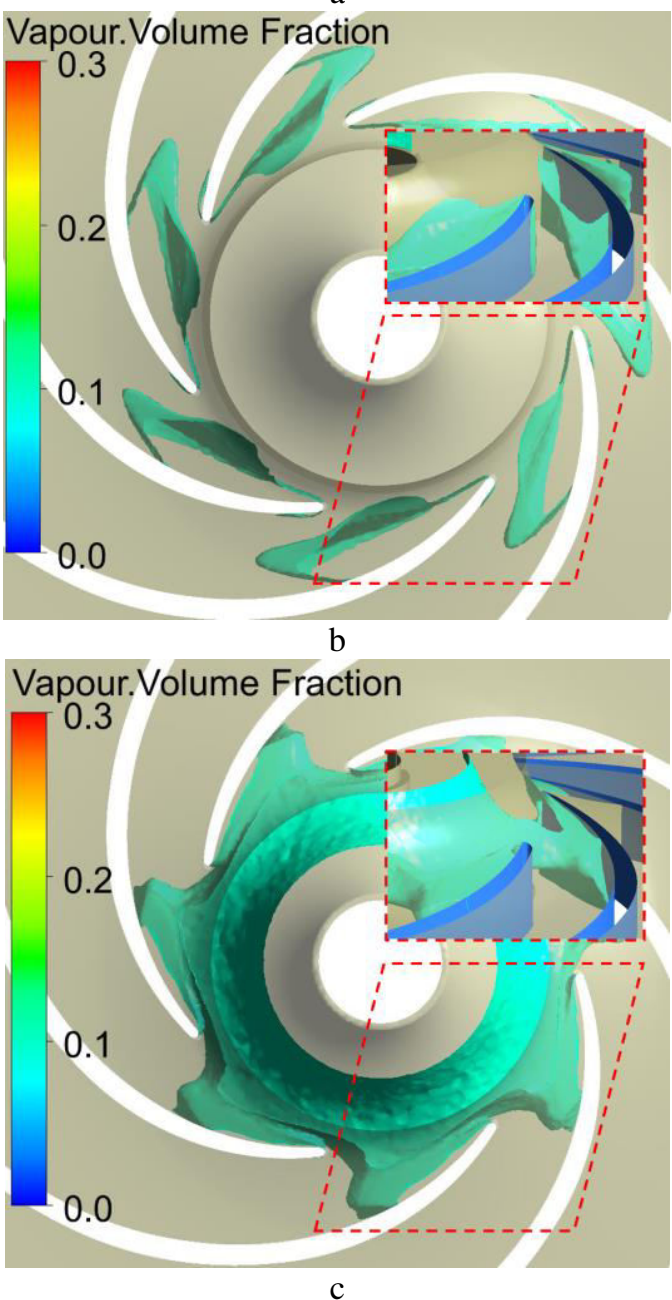

Figure 5 - The cavitation structure in the impeller at $Q_{\text {nom }}$ : $\mathrm{a}-$ AID $2 N P S H=1.71 \mathrm{~m} ; \mathrm{b}-$ AID $0 N P S H 3 \%=0.31 \mathrm{~m}$; $\mathrm{c}-\mathrm{AID} 2 \mathrm{NPSH} 3 \%=0.77 \mathrm{~m}$ 
The size of the cavitation zones and the content of water vapor increase, with the decreasing of the NPSH value. There is the uniform "growth" of the cavitation zone on the blades surface for the AID 0 (Fig. 5 b). There is a significant zone of the cavitation on the suction side of the blades, which occupies and overlaps about $2 / 3$ area of the passage between leading edges of neighboring blades at the NPSH $3 \%$ for the AID 0.

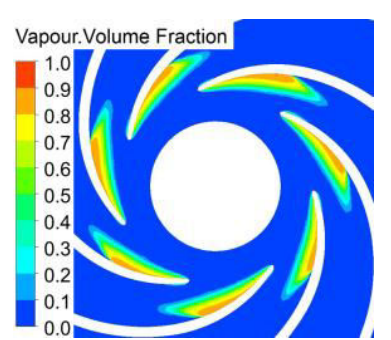

a

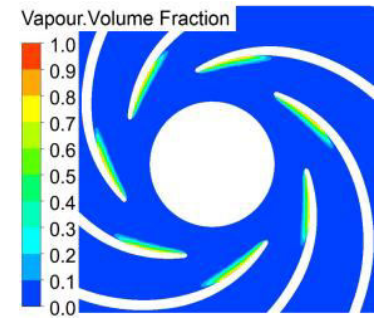

c

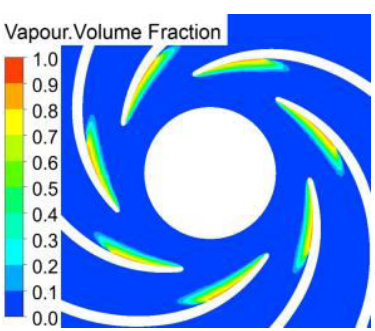

b

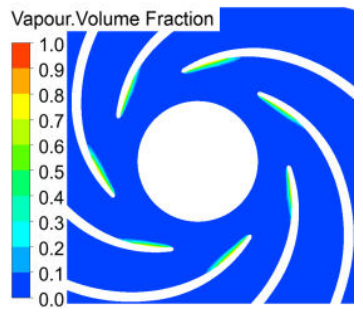

d

Figure 6 - The vapour volume fraction distribution in the impeller cross section at a distance of $3 / 4$ width of the blade from the front shroud at the leading edges at $Q_{\text {nom }}$ :

$\mathrm{a}-$ AID 0 NPSH $3 \%=0.31 \mathrm{~m}$; b - AID 1 NPSH $3 \%=0.51 \mathrm{~m}$; $\mathrm{c}-\mathrm{AID} 2 \mathrm{NPSH} 3 \%=0.77 \mathrm{~m} ; \mathrm{d}-\mathrm{AID} 3 \mathrm{NPSH} 3 \%=1.19 \mathrm{~m}$

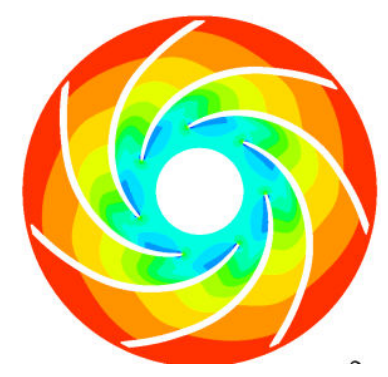

a Pressure

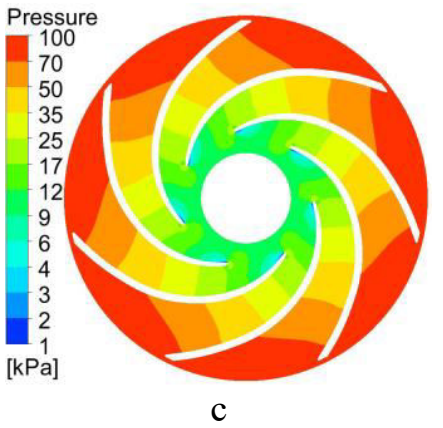

Figure 7 - The pressure distribution in the impeller cross section at a distance of $3 / 4$ width of the blade from the front shroud at the leading edges at $Q_{\text {nom }}$ for the AID 2 : a $-0.7 \cdot \mathrm{Q}_{\text {nom }}$

NPSH $3 \%=0.38 \mathrm{~m} ; \mathrm{b}-Q_{\text {nom }}$ NPSH $3 \%=0.77 \mathrm{~m}$; $\mathrm{c}-1.3 \cdot Q_{\text {nom }} N P S H 3 \%=1.31 \mathrm{~m}$
In the cases, for AIDs 1, 2, 3, there are larger cavitation zones in the impeller eye at the NPSH $3 \%$ than in the AID 0, which differs significantly in shape. They are located near the suction side of the blades and close to the front shroud (Fig. 5 c). Mentioned zones overlap 1/2 area of the passage between leading edges of neighboring blades. This was caused by the union of the cavitation zone of the diffuser with the cavitation zone in the impeller and the change in the direction of the absolute velocity at the impeller inlet. The reduction of the diameter of the AID causes the displacement of the cavitation zone in the impeller to the front shroud.

The vapour distribution in the impeller cross section at a distance of $3 / 4$ width of the blade from the front shroud at the leading edges demonstrates a decrease in the cavitation zone (Fig. 6), but really the cavitation zone just shifts to the front shroud. This confirms the above presented conclusions regarding the change in the cavitation zone (Fig. 5 b, c).

The distribution of the absolute pressure in the impeller at $(0.7,1.0,1.3) \cdot Q_{\text {nom }}$ is qualitatively similar (Fig. 7). However, larger areas of low pressure at the suction side of the blades near the leading edges are observed for a smaller value of the flow rate. This causes an increase in cavitation zones.
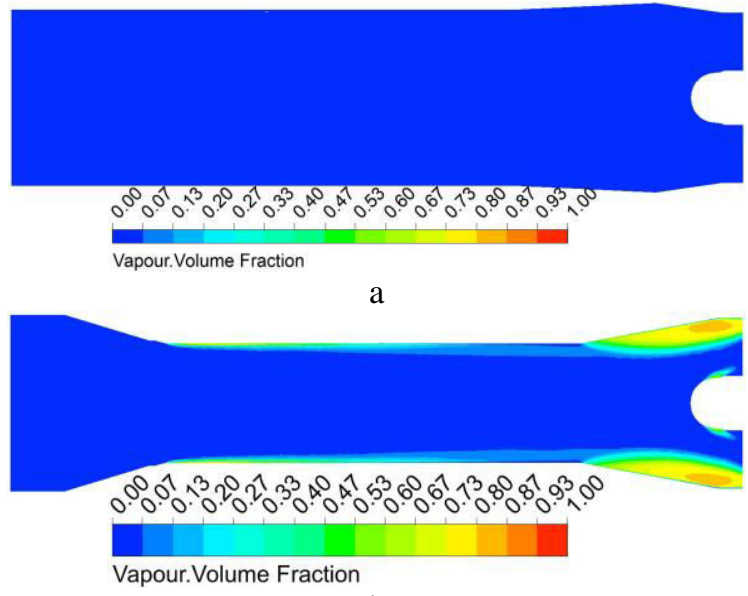

b
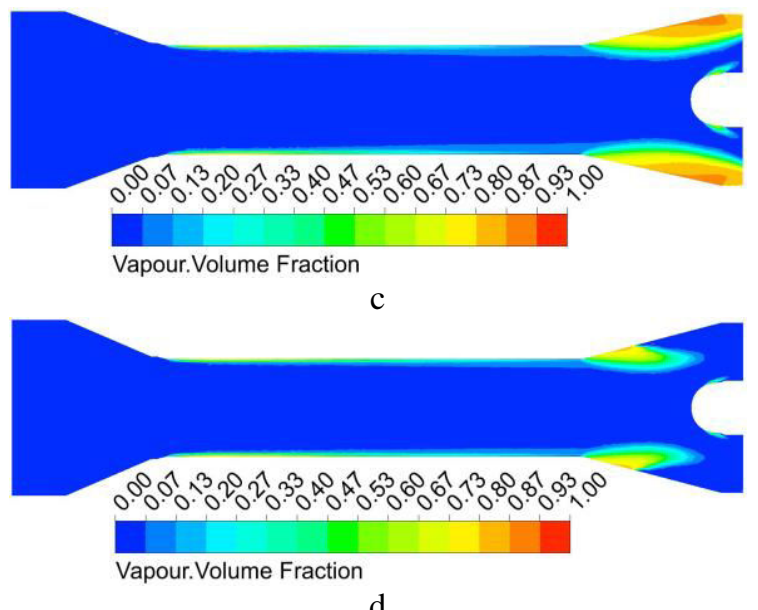

d

Figure 8 - The vapour volume fraction distribution in a longitudinal section of the AID at $Q_{\text {nom }}$ :

$\mathrm{a}-\mathrm{AID} 0 \mathrm{NPSH} 3 \%=0.31 \mathrm{~m} ; \mathrm{b}-\mathrm{AID} 1 \mathrm{NPSH} 3 \%=0.51 \mathrm{~m}$; $\mathrm{c}-\mathrm{AID} 2$ NPSH $3 \%=0.77 \mathrm{~m} ; \mathrm{d}-$ AID 3 NPSH $3 \%=1.19 \mathrm{~m}$ 
Cavitation in the AID 0 does not occur under the considered conditions (Fig. 8). There is an increase in the area of the cavitation zones in the diffuser section of the $A I D$, when the diameter is reduced and the diffuser angle is simultaneously increased, which is a consequence of the strengthening of the detachment process. It should be noted, that cavitation in the impeller begins earlier than in the AID. At the same time, the value of the required NPSH $(N P S H R=1.3 \cdot N P S H 3 \%)$ coincides with the first occurrence of cavitation in the AID and rather large cavitation zones in the impeller. That is, first of all, the destruction of the material through cavitation will be in the impeller. It should be noted, that there are significantly smaller zones of cavitation in the diffuser of the AID 3 compared_AIDs $0,1,2$, but there is an essential decrease in pressure.

Places of appears and structure of the cavitation zones are illustrated by the example of the AID 2 (Fig. 9). Cavitation almost simultaneously appears in two zones (Fig. 9 a). The first zone is after cone at the beginning of the straight section. The second zone is at the beginning of the diffuser section of the AID. The cavitation zones are similar in the AIDs 1, 2, and 3. These zones are rapidly increasing by area with decreasing NPSH value (Fig. 9 b). In addition, cavitation appears in the third zone, located near the fairing at the outlet of the diffuser section. The cavitation zone increases and overlaps bigger area at the impeller eye, which leads to the decrease of the flow diameter of the AID.
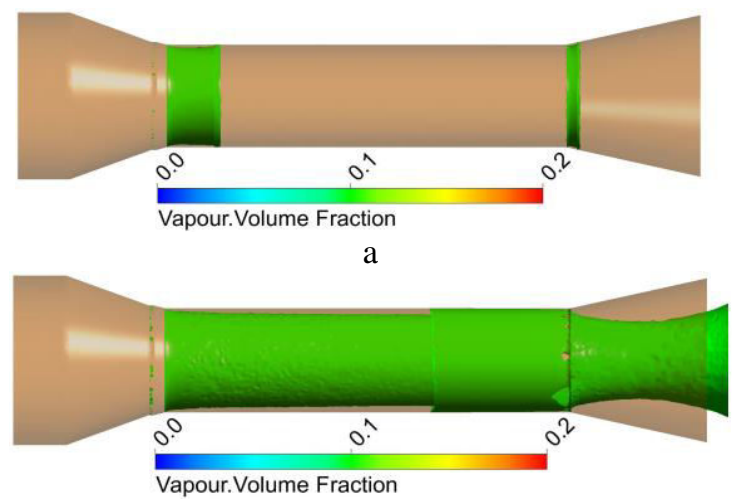

b

Figure $9-$ The cavitation structure in the $A I D 2$ at $Q_{\text {nom }}$ : $\mathrm{a}-N P S H=0.79 \mathrm{~m} ; \mathrm{b}-\mathrm{NPSH} 3 \%=0.77 \mathrm{~m}$

In general, Cucha et.al [10] described a similar process of cavitation occurrence like in the first zone. However, rotation of the walls causes its "blurring" and stretching of the vapor along the $A I D$ (Fig. 8, 9, 10), which is likely caused by the presence of a circular component of absolute velocity near the inner surface of the AID. "Blurring" is more prominent, with a larger diameter and, respectively, a larger circular component of the absolute velocity. Its intensity decreases, when decreasing the flow rate, which could be explained by the reduction in the axial component of the absolute velocity. This phenomenon is described in more detail at the publication [14].
The decrease of the flow rate causes the increase in the area of the cavitation zones in the AIDs 1,2,3 due to the increase of the absolute pressure in the outlet of diffuser and vice versa (Fig. 10).

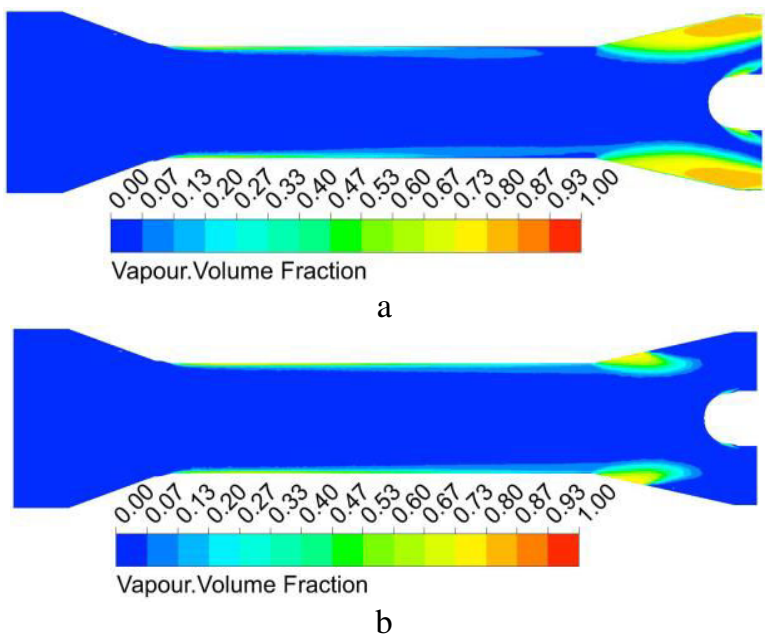

Figure 10 - The vapour volume fraction distribution in a longitudinal section of the AID 2: a $-0.7 \cdot Q_{\text {nom }} N P S H 3 \%=0.38 \mathrm{~m}$; $\mathrm{b}-1.3 \cdot Q_{\text {nom }} N P S H 3 \%=1.31 \mathrm{~m}$

The pictures of the absolute pressure distribution in the AIDs show the zones of the reduced pressure (Fig. 11), which correspond to the zones of the cavitation emergence. The first zone is after cone, the second zone is at the beginning of diffuser section, the third one is located near the fairing at the outlet of the diffuser section. These are the zones of the velocity increasing (due to the change in the cross-sectional area of the passage channel) and changes of the fluid flow direction. There is no zone with pressure below saturated vapor pressure in the AID 0 . The absolute pressure distribution is similar for the AIDs 1, 2, and 3 .
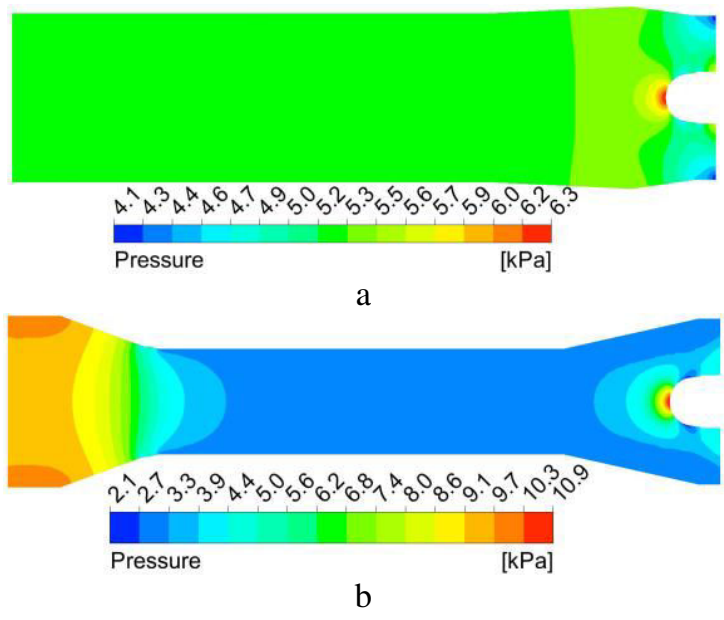

Figure 11 - The pressure distribution in a longitudinal section of AID at $Q_{\text {nom }}$ : a - AID 0 NPSH $3 \%=0.31 \mathrm{~m}$; $\mathrm{b}-\mathrm{AID} 2 \mathrm{NPSH} 3 \%=0.77 \mathrm{~m}$ 
A possible way of eliminating the first and the second zones of absolute pressure reduction is to use a curvilinear wall profile of the cone and diffuser. They have to ensure a smooth change in the diameter of the passage channel and, as a consequence, smooth flow around the walls. To remove the third zone, it is necessary to change the shape of the fairing, giving it a more conical shape.

\section{Conclusion}

The analysis of the presented results of the numerical simulations of the working process in the centrifugal pump and the physical experiments under the condition of alteration of the geometric parameters (diameter and, respectively, the angles of the cone and the diffuser) of the AID with rotating walls make it possible to do the following conclusions.

The curves of the cavitation characteristics of the analyzed pump have a similar shape, but determined by means of the experiment have higher values compare to CFD. This can be explained by different roughness (and it structure) of walls in numerical model and experimental and disregard volume losses.

The best cavitation performance has the pump with the basic AID. According to the results of the numerical experiment its equals NPSH $3 \%=0.3 \mathrm{~m}$ at $Q_{\text {nom }}$. The value of the NPSH $3 \%$ increases with decreasing diameter of the AID and proportional to the change of the flow rate. The maximum value of the NPSH $3 \%$ is $1.2 \mathrm{~m}$ for AID 3 at $Q_{\text {nom }}$.

The calculated values of the suction specific speed at $Q_{\text {nom }}$ for AID 0, 1, 2, and 3 are respectively 231, 160, 118, and 85 . The base AID has better performance than standard pumps, AID 1 has a permissible value and AID 2, and 3 have understated.

The cavitation in the impeller beginning earlier than in the AID. That is, the proposed design of the AID will not be endangered to the destruction if the pump is operating with pressure above the NPSHR.

The value of the NPSH $3 \%$ increases and the shape of the cavitation zones substantially change with the decrease in the diameter of the cylindrical section of the AID. The cavitation zones shifts to the suction side of the blades and the front shroud, while occupies to $1 / 2$ of the cross-sectional area of the passage between blades near leading edges. This is caused by the union of the cavitation zone of the diffuser with the cavitation zone in the impeller and the change in the direction of absolute velocity at the inlet to the impeller.

The rotation of the AID causes swirling flow character near its walls and, as a result, the separation from the walls and the "blurring" of the cavitation zones occurs. "Blurring" is more prominent, with a larger diameter and, respectively, a larger circular component of the absolute velocity. Its intensity decreases, when decreasing the flow rate, which is explained by the decrease in the axial component of absolute velocity.

The results of the conducted research show that in order to improve the cavitation performances of the AID of the centrifugal pump in the considered structure, it should be avoided abrupt transitions from cone to the cylindrical section, and then to the diffuser section of the AID. It is better to use curvilinear wall profile of the cone and diffuser.

\section{References}

1. Guo, X., Guo, X., Zhu, Z., Cui, B., \& Li, Y. (2012). Analysis of cavitation performance of inducers, centrifugal pumps. Centrifugal Pumps, doi: 10.5772/26744.

2. Jiang, J., Sun, Q., Liu, Y., Chen, Y., \& Yi, W. (2015). Numerical simulation of cavitation performance on a high-speed centrifugal pump with a variable pitch inducer. The 13th Asian International Conference on Fluid Machinery, Tokyo, Japan, September $7-10,2015$.

3. Tkach, P. Y, (2017). Influence of geometry parameters of inducer bush design on cavitation erosion characteristics of centrifugal inducer stage of pump. IOP Conference Series: Materials Science and Engineering, Vol. 233, doi: 10.1088/1757899X/233/1/012012.

4. Si, Q., Yuan, S., Yuan, J., \& Bois, G. (2016). Investigation on the influence of jetting equipment on the characteristics of centrifugal pump. Advances in Mechanical Eng, Vol. 8(8), pp. 1-11, doi: 10.1177/1687814016660287.

5. Tan, L.., Zhu, B., Cao, S., Wang, Y., \& Wang, B. (2014). Influence of prewhirl regulation by inlet guide vanes on cavitation performance of a centrifugal pump. Energies, Vol 7, pp. 1050-1065, doi: 10.3390/en7021050.

6. Tan, L., Zha, L., Cao, S. L., Wang, Y. C., \& Gui, S. B, (2015). Cavitation performance and flow characteristic in a centrifugal pump with inlet guide vanes. International Symposium of Cavitation and Multiphase Flow (ISCM 2014) IOP Conference Series: Materials Science and Engineering, Vol. 72, http://iopscience.iop.org/1757-899X/72/3/032028.

7. Skerlavaj, A., \& Pavlin, R. (2014). Effect of vortical structures on cavitation on impeller blades in pumps with suction chambers. IOP Conference Series: Earth and Environmental Science, 27th IAHR Symposium on Hydraulic Machinery and Systems, Vol. 22, doi: 10.1088/1755-1315/22/5/052002.

8. Nagahara, T., Sato, T., \& Okamura, T. (2003). Measurement of the flow around the submerged vortex cavitation in a pump intake by means of PIV. Fifth International Symposium on Cavitation (cav2003).

9. Sikora, R., Burecek, A., Hruzik, L., \& Vasina, M. (2015). Experimental investigation of cavitation in pump inlet. EPJ Web of Conferences, Vol. 22, doi: 10.1051/epjconf/20159202081.

10. Cunha, M. A. R., \& Nova, H. F. V. (2013). Cavitation modelling of a centrifugal pump impeller. 22-nd International Congress of Mechanical Engineering, San Paulo, Brazil, pp. 1633-1644. 
11. Hergt, P., Nicklas, A., Mollenkopf, G., \& Brodersen, S. (1996). The suction performance of centrifugal pumps possibilities and limits of improvements. Proceedings of the International Pump Users Symposium, Texas A\&M University System, pp. 13-26.

12. Gulich, J. F. (2014). Centrifugal Pumps. Springer, Berlin, Heidelberg, New York, doi: 10.1007/978-3-642-40114-5.

13. Limbach, P., Muller, T., Blume, M., \& Skoda R. (2016). Numerical and experimental investigation of the cavitation flow in a low specific speed centrifugal pump and assessment of the influence of surface roughness on head prediction. International Symposium on Transport Phenomena and Dynamics of Rotating Machinery, Hawaii.

14. Moloshnyi, O., \& Sotnyk, M. (2017). Cavitation in centrifugal pump with rotating walls of axial inlet device. IOP Conference Series: Materials Science and Engineering, Vol. 233, doi: 10.1088/1757-899X/233/1/012007.

15. Moloshnyi, O., \& Sotnyk, M. (2018) Influence of geometric dimensions of inlet device on the operating process of the pump. Industrial Hydraulics and Pneumatics, Vol 3(61) [in Ukrainian].

\title{
Вплив підвідного обертового осьового пристрою \\ на кавітаційні процеси у відцентровому насосі
}

\author{
Молошний О. М. ${ }^{1}$, Шульц П. ${ }^{2}$, Сотник М. I. ${ }^{1}$ \\ ${ }^{1}$ Сумський державний університет, вул. Римського-Корсикова, 2, 40007, м. Суми, Україна; \\ ${ }^{2}$ Вроцлавський університет науки і техніки, вул. Берег Вишпянскєго, 27, 50-370, м. Вроцлав, Польща
}

\begin{abstract}
Анотація. Робота присвячена аналізу кавітаційних процесів у проточній частині відцентрового насоса. Нова концепція двопотічного герметичного насоса потребує застосування спеціального підвідного пристрою, що входить до складу обертаючих елементів електродвигуна. Проаналізовано чотири моделі осьового підвідного пристрою. Перша є базовою і має циліндричну форму з незначною дифузорністю та конусом перед робочим колесом. Інші три мають нерухомий конус, який $є$ частиною корпусу, а також прямолінійну $\mathrm{i}$ дифузорну ділянки, що обертаються з частотою обертання вала насоса, а також обтічник сферичної форми. Дослідження проведено за допомогою фізичного експерименту і числового моделювання. Аналіз результатів показує, що насос із базовим підвідним пристроєм має кавітаційний запас вище середньостатистичного для подібної геометрії. Кавітаційні характеристики насоса, отримані числовим моделюваням і шляхом проведення фізичного експерименту, мають подібні форми, проте останні мають вищі значення. Кавітація у робочому колесі починається раніше, ніж в осьовому підвідному пристрої. Кавітаційні зони в осьовому підвідному пристрої розташовані після звуження поперечного перерізу - на початку дифузорної ділянки і біля обтічника на виході з дифузора. Кавітаційна зона, що знаходиться після конфузору, відривається від стінок осьового підвідного пристрою. При зменшенні діаметра в осьовому підвідному пристрої через втрати напору в ньому відбувається підвищення значення кавітаційного запасу.
\end{abstract}

Ключові слова: підвід, вхідний патрубок, робоче колесо, конфузор, дифузор, CFD, кавітаційний запас, кавітаційна характеристика. 